\title{
Complete blood count derived haematological parameters do not correlate with disease activity in patients with radiographic axial spondyloarthritis
}

\author{
Tam kan sayımından türetilen hematolojik parametreler radyografik aksiyel spondiloartritlerde \\ hastalık aktivitesi ile korele değildir

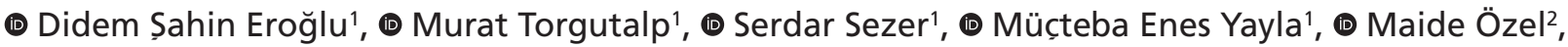

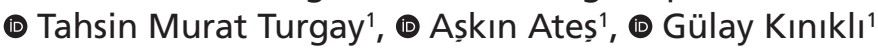 \\ ${ }^{1}$ Ankara University Faculty of Medicine, Department of Internal Medicine, Division of Rheumatology, Ankara, Turkey \\ ${ }^{2}$ Ankara University Faculty of Medicine, Department of Internal Medicine, Ankara, Turkey
}

\begin{abstract}
Objective: Low disease activity is aimed to preserve functional status in radiographic axial spondyloarthritis ( $r$-axSpA). However, disease activity indices use erythrocyte sedimentation rate (ESR) and C-reactive protein (CRP) levels, which might not uniformly reflect active disease. Complete blood count $(C B C)$ test is routinely performed in daily practice and components of $\mathrm{CBC}$ may reflect ongoing inflammation. In this singlecentred retrospective study, we aimed to determine the associations of CBC parameters with disease activity indices in $\mathrm{r}$-axSpA patients.

Methods: Patients and healthy controls, who presented to our rheumatology outpatient clinic from January 2018 to September 2020, were recruited to the study. Sixty-four patients diagnosed with r-axSpA were compared with sex- and age- matched 53 patients with Behçet's syndrome and 79 healthy controls. The demographic characteristics and laboratory parameters including CBC, ESR and CRP values of the participants were recorded. Disease activity indices such as Bath Ankylosing Spondylitis Disease Activity index (BASDAI) and Ankylosing Spondylitis Disease Activity score (ASDAS) were scrutinized. One-Way ANOVA and Spearman test were used to compare the groups and to calculate the correlation of parameters with disease activity indices, respectively. All statistics were done in SPSS version 21 with a $p$-value of $<0.05$ considered statistically significant.

Results: Demographic characteristics were similar among the groups. The mean platelet volume was significantly lower in r-axSpA patients than in diseased and healthy controls $(9.8 \pm 0.9$ vs $10.3 \pm 0.8$ vs 10.4 0.9 , respectively, $p=0.001)$. $C B C$ components did not correlate with BASDAI and ASDAS. Neutrophil-lymphocyte ratio and plateletlymphocyte ratio were weakly correlated with CRP ( $r=0.399$ and 0.316 , respectively)
\end{abstract}

Conclusion: $C B C$ components do not indicate disease activity in r-axSpA.

Keywords: Ankylosing spondylitis, radiographic axial spondyloarthritis, mean platelet volume, BASDAI, ASDAS

\section{Öz}

Amaç: Radyografik aksiyal spondiloartritte ( $r$-axSpA) düșük hastalık aktivitesi sağlanarak fonksiyonel durumun korunması amaçlanmaktadır. Ancak halen kullanılmakta olan hastalık aktivite indeksleri eritrosit sedimentasyon hızı (ESH) ve C-reaktif protein (CRP) gibi aktif hastalığı net olarak yansıtmayan parametreleri kullanmaktadır. Tam kan sayımı (TKS) testi günlük pratikte rutin olarak kullanılmaktadır ve TKS'nin bileșenleri devam eden enflamasyonu yansitabilir. Bu tek merkezli retrospektif çalıșmamızda, $r$-axSpA hastalarında TKS parametrelerinin hastalık aktivite indeksleri ile ilișkisini belirlemeyi amaçladık.

Yöntem: Ocak 2018-Eylül 2020 tarihleri arasında romatoloji polikliniğimize bașvuran hastalar ve sağlıklı kontroller çalıșmaya alındı. Altmıș dört r-axSpA tanısı olan hasta, cinsiyet ve yaș eșleștirilmiș 53 Behçet sendromlu hasta ve 79 sağlıklı kontrol ile karșılaștıııldı. Hastaların demografik özellikleri, TKS, ESH ve CRP gibi laboratuvar parametreleri kaydedildi. Bath Ankilozan Spondilit Hastalık Aktivite indeksi (BASDAI) ve Ankilozan Spondilit Hastalığı Aktivite skoru (ASDAS) gibi hastalık aktivite indeksleri kaydedildi. Grupları karssılaștırmak ve parametrelerin hastalık aktivite indeksleri ile korelasyonunu hesaplamak için sırasıyla tek yönlü ANOVA ve Spearman testi kullanıldı. Tüm istatistikler SPSS 21 versiyonunda yapııdı ve $p$ değeri $<0,05$ anlamlı kabul edildi.

Bulgular: Demografik özellikler gruplar arasında benzerdi. Ortalama trombosit hacmi $r$-axSpA hastalarında, hastalıklı ve sağlıklı kontrollere göre anlamlı derecede daha düșüktü (sırasıyla 9,8 $00,9,10,3 \pm 0,8$, $10,4 \pm 0,9, p=0,001)$. TKS bileșenleri BASDAI ve ASDAS ile korele değildi. Nötrofil-lenfosit oranı ve trombosit-lenfosit oranı, CRP ile zayıf bir șekilde korelasyon gösterdi (sırasıyla $r=0,399$ ve 0,316).

Sonuç: TKS bileșenleri r-axSpA'da hastalık aktivitesini göstermez.

Anahtar Kelimeler: Ankilozan spondilit, radyografik aksiyel spondiloartrit, ortalama trombosit hacmi, BASDAl, ASDAS

İletișim / Correspondence:

Didem Șahin Eroğlu, Ankara University Faculty of Medicine, Department of Internal Medicine, Division of Rheumatology, Ankara, Turkey

Tel.: +90 3125082234 E-posta: dr.didemsa@gmail.com ORCID ID: orcid.org/0000-0003-3558-5400

Geliș Tarihi / Received: 23.11.2020 Kabul Tarihi / Accepted: 18.03.2021

Atıf / Cite this article as: Șahin Eroğlu D, Torgutalp M, Sezer S, Enes Yayla M, Özel M, Turgay TM, Ateș A, Kınıklı G. Complete blood count derived

haematological parameters do not correlate with disease activity in patients with radiographic axial spondyloarthritis. Ulus Romatol Derg 2021;13(1):6-11

๑Telif Hakkı 2021 Türkiye Romatoloji Derneği / Ulusal Romatoloji Dergisi, Galenos Yayınevi tarafından yayınlanmıștır.

${ }^{\odot}$ Copyright 2021 by the Turkish Society for Rheumatology / Journal of Turkish Society for Rheumatology published by Galenos Publishing House. 


\section{Introduction}

Radiographic axial spondyloarthritis (r-axSpA) or ankylosing spondylitis (AS) is an inflammatory disease characterized by the involvement of mainly the sacroiliac joints and the spine. ${ }^{[1]}$ Erythrocyte sedimentation rate (ESR) and C-reactive protein (CRP) levels have been used for the assessment of disease activity in $\mathrm{r}$-axSpA as well as Bath AS Disease Activity index (BASDAI), which includes patient-reported outcomes. ${ }^{[2]}$ However, high ESR and CRP levels are detected in 40-50\% of patients with r-axSpA, and they do not always reflect the actual disease activity. [3-5] Therefore, the combination of outcomes reported by patient and laboratory activity parameters, ESR and CRP, are used for the assessment of the Ankylosing Spondylitis Disease Activity score (ASDAS). ${ }^{[6]}$ In recent years, there are increasing data about the usage of haematological markers such as the neutrophil-lymphocyte ratio (NLR), the platelet-lymphocyte ratio (PLR), the mean platelet volume (MPV), red cell distribution width (RDW), and the lymphocyte-monocyte ratio (LMR) in rheumatic diseases. Complete blood count (CBC) test is routinely used in diagnosis and follow-ups of patients with $\mathrm{r}$-axSpA and other rheumatic diseases. It is simple and has no additional cost for the evaluation work-up. NLR, PLR, MPV, RDW and LMR are the haematological parameters derived from CBC. It has been shown that these parameters could reflect disease activity in other rheumatic diseases such as systemic lupus erythematosus (SLE), systemic sclerosis (SSc), and rheumatoid arthritis (RA) ${ }^{[7-9]}$ Nevertheless, there are conflicting results in the literature evaluating these haematological parameters and disease activity in patients with r-axSpA. ${ }^{[10-13]}$

There is still an unmet need to define simple biomarkers, and to test the accuracy of laboratory biomarkers related to $\mathrm{CBC}$ for the assessment of disease activity in patient with r-axSpA. The aim of this study was to evaluate the relationship between these parameters and disease activity in $\mathrm{r}$-axSpA patients.

\section{Materials and Methods}

In this retrospective, single-centre, cross-sectional study, 64 patients with r-axSpA, who were classified according to modified New York criteria and who applied to our rheumatology outpatient clinic, were included. ${ }^{[14]}$ Fifty-three patients with BS, who fulfilled international study group criteria, were accepted as the diseased control group. ${ }^{[15]}$ Patients with active infection and/or malignancy and pregnant women at the recruitment time were not included into the study, as well as patients whose complete medical records were not available. As a healthy control group, 74 people were recruited into the study. Demographic characteristics of the groups (such as sex and age), haematological parameters that included neutrophil, lymphocyte, platelet counts, RDW, MPV in CBC, ESR and CRP levels were recorded by using electronical database of Ankara University Faculty of Medicine. Haematological parameters such as NLR, PLR, MPV and LMR were calculated by using the patients' CBC results. For the evaluation of disease activity and function in r-axSpA patients, BASDAI, ASDAS, and Bath AS Disease Functional index (BASFI) scores were obtained from patients' electronical medical records. Laboratory markers and disease activity indices were evaluated in the same visit with respect to cross-sectional design of the study.

This study was approved by the local research ethics committee of the Ankara University Faculty of Medicine (approval number: I9-586-20). The study was conducted according to the Declaration of Helsinki.

\section{Statistical Analysis}

Statistical Package for the Social Sciences (SPSS) version 21 was performed for statistical analyses. Data were shown as total numbers and percentages for categorical variables. Disease duration was given as the median and interquartile range (IQR). The variables were considered using analytical (Kolmogorov-Smirnov/Shapiro-Wilk's test) and visual (histograms, probability plots) methods to control the normal distribution. The chi-square or Fisher's Exact test was used to analyze proportions in diverse groups. Independent sample t-test (or Mann-Whitney $U$ test as a non-parametric substitute) and ANOVA (or Kruskal Wallis test as a nonparametric substitute) were used to analyze the differences between extracted groups, followed by post-hoc tests with Bonferroni correction. The correlation coefficients and their significance were calculated by using the Spearman test. A p-value of $<0.05$ was considered statistically significant.

\section{Results}

There were not any differences with regard to demographic characteristics of three groups (Table 1). Among r-axSpA patients, 36 patients (56.3\%) were male and diagnosed at an age of $34.3 \pm 12.5$ years. The mean age at the study recruitment was $43.3 \pm 11.0$ years in $\mathrm{r}$-axSpA group. The median disease duration was 7.4 years (IQR 8.00). Among extra axial SPA features, the most common involvement was enthesitis (31.3\%) followed by peripheral arthritis (29.7\%), uveitis $(18.8 \%)$, psoriasis $(10.9 \%)$, inflammatory bowel disease $(7.8 \%)$ and dactilitis (3.1\%). HLA-B27 results were available in 29 patients, 17 of whom were positive. Acute phase reactans (APRs), either CRP or ESR, were high in 38 
patients $(59.4 \%)$, whereas 26 patients $(40.6 \%)$ had normal APRs.

Among 53 patients with BS, genital ulcer was seen in $46(86.8 \%)$ patients. Forty-three $(81.1 \%)$ patients had either papulopustular eruption or erythema nodosum. Musculoskeletal involvement was seen in 33 (62.3\%) patients. Major organ involvements such as ocular, vascular, neurological and gastrointestinal involvement were present in $33(62.3 \%)$ patients. The mean age at BS diagnosis was $28.8 \pm 9.3$ years. The median disease duration was 12.0 years (IQR 14.5).

When we compared haematological parameters in r-axSpA patients, patients with BS and healthy controls, platelet and neutrophil counts were higher in the patients with $\mathrm{r}$-axSpA than in the healthy group. While there was no difference in NLR, PLR and RDW values between the r-axSpA and control groups, only the MPV values in the r-axSpA group were significantly lower compared to the healthy controls and the BS group $(\mathrm{p}=0.001)$ (Figure 1).

Considering the patients with BS, RDW was significantly higher in BS patients than in other two groups. Likewise, NLR was significantly higher than in the healthy subjects but NLR was similar to r-axSpA patients. Haemoglobin levels also differed in BS group from healthy subjects and patients with r-axSpA.

In r-axSpA group, overall BASDAI score and ASDASCRP were $3.95 \pm 2.52$ and $2.64 \pm 1.17$, respectively. BASDAI score of 34 patients $(53.1 \%)$ was higher than 4 , whereas

Table 1. Clinical characteristics and laboratory parameters of the groups

\begin{tabular}{|c|c|c|c|c|}
\hline & $\begin{array}{c}r-a x S p A \\
(n=64)\end{array}$ & $\begin{array}{c}\text { BS } \\
(n=53)\end{array}$ & $\begin{array}{l}\text { Healthy } \\
\text { control } \\
(n=79)\end{array}$ & p-value \\
\hline Age, years & $43.3 \pm 11.0$ & $41.9 \pm 10.9$ & $43.7 \pm 14.2$ & 0.73 \\
\hline Sex, male, n (\%) & $36(56.3)$ & $33(62.3)$ & $42(53.2)$ & 0.58 \\
\hline Hemoglobin, g/dL & $14.1 \pm 1.7$ & $13.3 \pm 1.5$ & $13.9 \pm 1.6$ & 0.013 \\
\hline RDW (\%) & $13.4 \pm 1.4$ & $14.2 \pm 1.4$ & $13.3 \pm 1.3$ & 0.002 \\
\hline Platelet count (x109/L) & $312 \pm 86$ & $281 \pm 75$ & $271 \pm 62$ & 0.003 \\
\hline MPV & $9.8 \pm 0.9$ & $10.3 \pm 0.8$ & $10.4 \pm 0.9$ & 0.001 \\
\hline $\begin{array}{l}\text { Neutrophil count } \\
(\times 109 / L)\end{array}$ & $5.0 \pm 2.1$ & $4.9 \pm 1.8$ & $4.1 \pm 1.2$ & 0.004 \\
\hline $\begin{array}{l}\text { Lymphocyte count } \\
\text { (x109/L) }\end{array}$ & $2.7 \pm 0.9$ & $2.3 \pm 0.8$ & $2.2 \pm 0.6$ & $<0.001$ \\
\hline NLR & $2.05 \pm 1.03$ & $2.53 \pm 1.64$ & $1.93 \pm 0.54$ & 0.007 \\
\hline PLR & $127 \pm 50$ & $141 \pm 66$ & $130 \pm 39$ & 0.329 \\
\hline ESR, mm/hour & $15.1 \pm 14.3$ & $14.8 \pm 13.2$ & $10.2 \pm 7.8$ & 0.021 \\
\hline High ESR, n (\%) & $13(20.3)$ & $11(20.8)$ & $6(7.6)$ & 0.048 \\
\hline CRP, mg/L & $11.0 \pm 15.7$ & $10.0 \pm 18.9$ & $2.7 \pm 2.4$ & $<0.001$ \\
\hline High CRP, n (\%) & $35(54.7)$ & $20(37.7)$ & $10(12.7)$ & $<0.001$ \\
\hline \multicolumn{5}{|c|}{$\begin{array}{l}\text { BS: Behçet's syndrome, CRP: C-reactive protein, ESR: Erythrocyte sedimentation } \\
\text { rate, MPV: Mean platelet volume, NLR: Neutrophil-lymphocyte ratio, PLR: Platelet- } \\
\text { lymphocyte ratio, r-axSpA: Radiographic axial spondyloarthritis, RDW: Red cell } \\
\text { distribution width }\end{array}$} \\
\hline
\end{tabular}

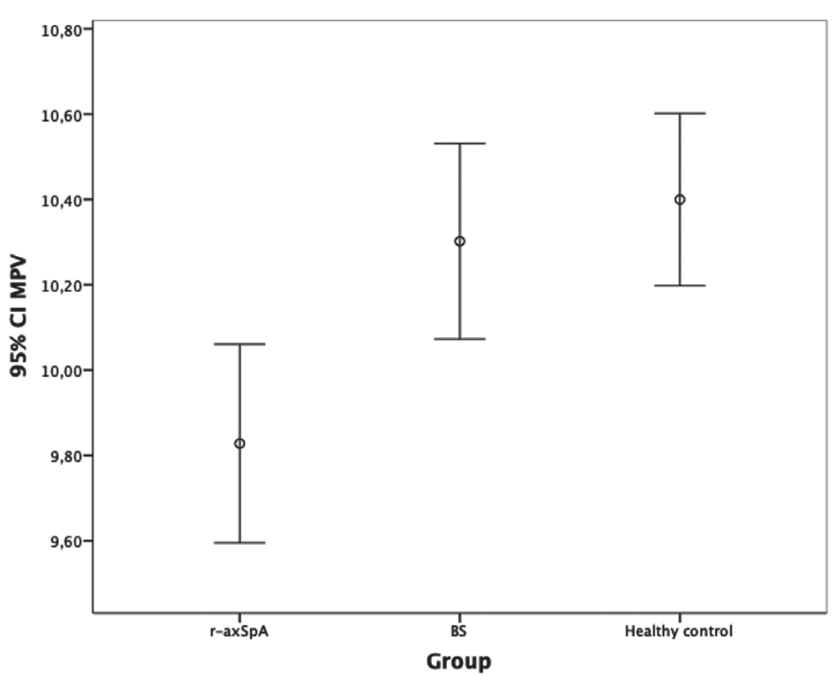

Figure 1. MPV values in patients with $r-a x S p A$ and $B S$, and healthy controls BS: Behçet's syndrome, MPV: Mean platelet volume, r-axSpA: Radiographic axial spondyloarthritis (Post-hoc test results; for $r$-axSpA and $B S, p=0.013$; for $\mathrm{r}$-axSpA and healthy control, $\mathrm{p}=0.001$ )

41 patients (64.0\%) had high or very high disease activity according to their ASDAS-CRP. Within patients with r-axSpA, when NLR was compared between the patients with BASDAI $\geq 4$ and with $<4$, there was not significant difference between the groups (median 1.82 vs 1.70 , respectively, $\mathrm{p}=0.81$ ). PLR, MPV and RDW were also similar between the groups ( $\mathrm{p}$-values are $0.97,0.48$ and 0.78 respectively). Furthermore, when evaluating according to ASDAS-CRP, NLR, PLR, MPV and RDW were not significantly different between the patients with an ASDAS $<2.1$ and with an ASDAS $>=2.1$ (p-values are 0.27, 0.28, 0.94 and 0.57 respectively). No significant correlation was found between disease activity indices and haematological parameters in the whole group (Table 2) and when patients were divided according to high/normal APRs levels (data not shown). Only CRP level was weakly correlated with NLR and PLR (Table 2).

Among r-axSpA group, biological disease modifying antirheumatic drugs (bDMARDs) were being used in 30 patients (46.9\%). The remaining 34 patients (53.1\%) were being treated with either conventional DMARDs (cDMARDs) and/or non-steroidal anti-inflammatory drugs. None of the patients among r-axSpA group were using glucocorticoids. Haematological parameters and activity indices did not differ between different treatment groups (data not shown).

In patients with BS, most commonly used agent was colchicine (90.6\%). Four patients (7.5\%) took prednisolone $\leq 7.5 \mathrm{mg}$ per day. Glucocorticoids had no effect on haematological parameters (data not shown). 
Table 2. Correlation of hematological parameters with disease activity indices and acute phase reactants in radiographic axial spondyloarthritis patients

\begin{tabular}{cccccc}
\hline & & RDW & MPV & NLR & PLR \\
\hline \multirow{2}{*}{ BASDAI } & $r$ & 0.137 & 0.100 & 0.074 & 0.029 \\
\cline { 2 - 6 } & $p$ & 0.281 & 0.433 & 0.563 & 0.822 \\
\hline \multirow{2}{*}{ BASFI } & $r$ & 0.069 & 0.092 & -0.002 & -0.067 \\
\cline { 2 - 6 } & $p$ & 0.589 & 0.471 & 0.989 & 0.599 \\
\hline \multirow{2}{*}{ ASDAS } & $r$ & 0.107 & 0.014 & 0.216 & 0.157 \\
\cline { 2 - 6 } & $p$ & 0.399 & 0.914 & 0.087 & 0.216 \\
\hline \multirow{2}{*}{ ESR } & $r$ & 0.147 & 0.120 & 0.085 & 0.217 \\
\cline { 2 - 6 } & $p$ & 0.246 & 0.345 & 0.503 & 0.085 \\
\hline \multirow{2}{*}{ CRP } & $r$ & 0.008 & -0.226 & 0.399 & 0.316 \\
\cline { 2 - 6 } & $p$ & 0.950 & 0.072 & 0.001 & 0.011 \\
\hline
\end{tabular}

ASDAS: Ankylosing Spondylitis Disease Activity score, BASDAl: Bath Ankylosing Spondylitis Disease Activity index, BASFl: Bath Ankylosing Spondylitis Functional index, CRP: C-reactive protein, ESR: Erythrocyte sedimentation rate, MPV: Mean platelet volume, NLR: Neutrophil-lymphocyte ratio, PLR: Platelet-lymphocyte ratio, r-axSpA: Radiographic axial spondyloarthritis, RDW: Red cell distribution width

\section{Discussion}

ESR and CRP levels are widely used as disease activity parameters along with other indices in systemic autoimmune rheumatic diseases, but serum levels are affected by several other conditions, and normal levels do not consistently exclude active disease. These drawbacks of conventional APRs lead to the search of other parameters reflecting disease activity. CBC components such as neutrophils and platelets play a pivotal role in inflammation and secrete a wide range of cytokines which activate innate and adaptive immunity. ${ }^{[16-18]}$ The interactions of these cell types are complex and play a pivotal role in disease pathogenesis. Ongoing chronic inflammation alters bone marrow homeostasis, and this alteration results in changes of blood cell parameters. It has been shown that peripheral bloodderived markers are different from healthy individuals and might indicate prognosis in some types of cancer. ${ }^{[19-}$ ${ }^{23]}$ Besides, decreased MPV level has been noted in active inflammatory bowel diseases. ${ }^{[24]}$ Moreover, in a populationbased study, a negative correlation between MPV and CRP was also described. ${ }^{[25]}$ Likewise, blood cell parameters might be used for the assessment of inflammation, which is evident almost in every active autoimmune rheumatic disease. The present study assessed the relation between disease activity and CBC parameters in patients with $\mathrm{r}$-axSpA.

In the case of RA, it has been shown by several articles that NLR and PLR are associated with disease activity score 28 (DAS 28). ${ }^{[26,27]}$ Furthermore, in a recent paper published, their positive correlation with ultrasonographic parameters of disease activity such as power doppler was also determined. ${ }^{[28]}$ Likewise, NLR and PLR reflected disease activity in SLE, and the existence of lupus nephritis was also associated with higher NLR and/or PLR values. [29,30] These results were consolidated by a meta-analysis as well. ${ }^{[31]}$ However, in our study, NLR and PLR were similar between patients with r-axSpA and healthy controls; they were only weekly correlated with CRP levels, which might reflect ongoing inflammatory state in $\mathrm{r}$-axSpA. These results are in line with a recently performed meta-analysis which compared CBC parameters of $\mathrm{r}$-axSpA patients and healthy controls. ${ }^{[10]}$ These results might be the result of different pathophysiological mechanisms of the diseases.

The results of our study are consistent with some respects of previous studies performed in patients with r-axSpA. We showed that MPV levels in $\mathrm{r}$-axSpA group were lower than in two control groups, but any other haematological parameters including MPV did not indicate active disease in $\mathrm{r}$-axSpA. MPV reflects the platelet size and is considered as a relatively reliable marker of thrombopoiesis and platelet function. ${ }^{[32]}$ Many rheumatological conditions, in which cytokines such as interleukin-1, interleukin-6 and tumor necrosis factor alpha are secreted excessively, result in low MPV levels. ${ }^{[33,34]}$ Low levels of MPV in r-axSpA patients were also demonstrated in a study conducted by Kisacik et al. ${ }^{[13]}$, which showed that MPV was lower in active RA and r-axSpA patients compared to healthy controls; however, MPV levels increased after the treatment of RA and r-axSpA, reflecting a negative association between MPV and disease activity. Another study conducted in Turkey in r-axSpA patients revealed that RDW was positively correlated with BASDAI, ESR and CRP levels with a cut-off value $14.8 \%$ in contrast to MPV which was not related to BASDAI scores. ${ }^{[12]}$ Mercan et al. ${ }^{[35]}$ also showed that NLR was correlated with ESR and CRP levels but not with BASDAI, which is consistent with our results. In a recent study from Chinese population, there was no relation between ASDAS-CRP and haematological parameters. ${ }^{[1]}$ In a systematic review and meta-analysis, which assessed the articles from Asia, Turkey and Middle East, elevated levels of RDW were found to be associated with r-axSpA, whereas MPV levels were not. ${ }^{[36]}$ These inconsistent results might stem from the heterogeneity of the study populations.

BS is considered as an MHC-I-opathy, sharing similar pathogenetic mechanisms with spondyloarthropathies. ${ }^{[37]}$ Given the fact that both diseases have some similarities with respect to pathophysiological pathways, it was more appropriate to use BS as diseased controls. Neutrophils play a major role in the etiopathogenesis of BS. ${ }^{[38,39]}$ In a study published from Turkey, NLR was found to be an indicator of BS presence. ${ }^{[40]}$ In addition, NLR was shown to be 
associated with active disease, especially with mucocutaneous involvement. ${ }^{[4]} \mathrm{RDW}$ was found to be associated with BS as well. ${ }^{[42,43]}$ In this report, we also showed that NLR and RDW were higher in patients with BS, consistent with the literature.

\section{Study Lìmitations}

The major limitation of our study is its retrospective and cross-sectional design. In addition, there were not any patients with non-radiographic axial spondyloarthritis, which represents an earlier phase of the disease and in which inflammation (in magnetic resonance imaging and/or CRP) plays more role than $\mathrm{r}$-axSpA. As a result, the duration of the illness was longer, which precludes us from making an assumption about the relation of these parameters in earlier disease. Furthermore, due to cross-sectional design of the study, the analyses were also based on a single measurement of $\mathrm{CBC}$, which may not reflect the relation over time. Therefore, we cannot predict the association between these haematological parameters and radiographic progression in patients with $\mathrm{r}-\mathrm{axSpA}$.

\section{Conclusion}

Our results indicate that haematological parameters such as NLR, PLR, MPV and RDW do not associate with commonly used disease activity indices of r-axSpA. Considering the conflicting results of the studies published about CBC-derived haematological parameters and the lack of the standardized measurement techniques, we believe that these parameters do not really help physicians to determine disease activity. As clinicians, we still need quick and accurate biomarkers that reflects the actual disease activity in patients with r-axSpA. More studies need to be conducted to ascertain prospective biomarkers for disease activity in $\mathrm{r}$-axSpA.

\section{Ethics}

Ethics Committee Approval: This study was approved by the local research ethics committee of the Ankara University Faculty of Medicine (approval number: I9-58620). The study was conducted according to the Declaration of Helsinki.

Informed Consent: Retrospective study.

Peer-review: Externally and internally peer-reviewed.

\section{Authorship Contributions}

Concept: D.Ş.E., M.T., G.K., Design: D.Ş.E., M.T., M.E.Y., Data Collection or Processing: D.Ş.E., M.Ö.,
Analysis or Interpretation: M.T., T.M.T., A.A., Literature Search: D.Ş.E., S.S., M.E.Y., Writing: D.Ş.E., M.T., G.K.

Conflict of Interests: No conflict of interests was declared by the authors.

Financial Disclosure: The authors declared that this study received no financial support.

\section{References}

1. Zhu W, He X, Cheng K, et al. Ankylosing spondylitis: etiology, pathogenesis, and treatments. Bone Res 2019;7:22.

2. Garrett S, Jenkinson T, Kennedy LG, Whitelock H, Gaisford P, Calin A. A new approach to defining disease status in ankylosing spondylitis: the bath ankylosing spondylitis disease activity index. J Rheumatol 1994;21:2286-91.

3. Rudwaleit M, Haibel H, Baraliakos X, et al. The early disease stage in axial spondylarthritis: results from the German Spondyloarthritis Inception Cohort. Arthritis Rheum 2009;60:717-27.

4. Ruof J, Stucki G. Validity aspects of erythrocyte sedimentation rate and C-reactive protein in ankylosing spondylitis: a literature review. J Rheumatol 1999;26:966-70.

5. Spoorenberg A, van der Heijde D, de Klerk E, et al. Relative value of erythrocyte sedimentation rate and C-reactive protein in assessment of disease activity in ankylosing spondylitis. J Rheumatol 1999;26:980-4.

6. Lukas C, Landewé R, Sieper J, et al. Development of an ASASendorsed disease activity score (ASDAS) in patients with ankylosing spondylitis. Ann Rheum Dis 2009;68:18-24.

7. Wang L, Wang C, Jia X, Yang M, Yu J. Relationship between neutrophil-to-lymphocyte ratio and systemic lupus erythematosus: a meta-analysis. Clinics (Sao Paulo) 2020;75:e1450. doi:10.6061/ clinics/2020/e1450

8. Yayla ME, İlgen U, Okatan IE, et al. Association of simple hematological parameters with disease manifestations, activity, and severity in patients with systemic sclerosis. Clin Rheumatol 2020;39:77-83.

9. Zengin $\mathrm{O}$, Onder ME, Kalem A, et al. New inflammatory markers in early rheumatoid arthritis. Z Rheumatol 2018;77:144-150.

10. Song GG, Lee YH. Red cell distribution width, platelet-tolymphocyte ratio, and mean platelet volume in ankylosing spondylitis and their correlations with inflammation: a metaanalysis. Mod Rheumatol 2020;30:894-9.

11. Seng JJB, Kwan YH, Low LL, Thumboo J, Fong WSW. Role of neutrophil to lymphocyte ratio (NLR), platelet to lymphocyte ratio (PLR) and mean platelet volume (MPV) in assessing disease control in Asian patients with axial spondyloarthritis. Biomarkers 2018;23:335-8.

12. Sezgin M, Tecer D, Kanık A, et al. Serum RDW and MPV in ankylosing spondylitis: can they show the disease activity? Clin Hemorheol Microcirc 2017;65:1-10.

13. Kisacik B, Tufan A, Kalyoncu U, et al. Mean platelet volume (MPV) as an inflammatory marker in ankylosing spondylitis and rheumatoid arthritis. Joint Bone Spine 2008;75:291-4.

14. van der Linden S, Valkenburg HA, Cats A. Evaluation of diagnostic criteria for ankylosing spondylitis. A proposal for modification of the New York criteria. Arthritis Rheum 1984;27:361-8. 
15. Criteria for diagnosis of Behcet's disease. International study group for Behcet's disease. Lancet 1990;335:1078-80.

16. Mantovani A, Cassatella MA, Costantini C, Jaillon S. Neutrophils in the activation and regulation of innate and adaptive immunity. Nat Rev Immunol 2011;11:519-31.

17. Jaillon S, Galdiero MR, Del Prete D, Cassatella MA, Garlanda C, Mantovani A. Neutrophils in innate and adaptive immunity. Semin Immunopathol 2013;35:377-94.

18. Semple JW, Italiano JE, Jr., Freedman J. Platelets and the immune continuum. Nat Rev Immunol 2011;11:264-74.

19. Fu S, Liu L, Zhang X, Liu ZP, Wang RT. Platelet indices in laryngeal cancer. Cancer Biomark 2018;21:675-80.

20. Yang W, Chen YY, Bi C, et al. Predictive and prognostic values of preoperative platelet parameters in patients with gynecological tumors. J Clin Lab Anal 2020;34:e23295. doi:10.1002/jcla.23295.

21. Gu L, Wang M, Cui X, et al. Clinical significance of peripheral blood-derived inflammation markers in advanced gastric cancer after radical resection. BMC Surg 2020;20:219.

22. Zhao G, Liu N, Wang S, et al. Prognostic significance of the neutrophil-to-lymphocyte and platelet-to-lymphocyte ratio in patients with metastatic gastric cancer. Medicine (Baltimore) 2020;99:e19405. doi:10.1097/md.0000000000019405

23. Liu J, Li S, Zhang S, et al. Systemic immune-inflammation index, neutrophil-to-lymphocyte ratio, platelet-to-lymphocyte ratio can predict clinical outcomes in patients with metastatic nonsmall-cell lung cancer treated with nivolumab. J Clin Lab Anal 2019;33:e22964. doi:10.1002/jcla.22964

24. Kapsoritakis AN, Koukourakis MI, Sfiridaki A, et al. Mean platelet volume: a useful marker of inflammatory bowel disease activity. Am J Gastroenterol 2001;96:776-81.

25. Ball S, Dennis JA, Bedanie G, Nugent K. Relation between mean platelet volume and C-reactive protein. Proc (Bayl Univ Med Cent) 2020;33:163-8.

26. Uslu AU, Küçük A, Şahin A, et al. Two new inflammatory markers associated with Disease Activity Score-28 in patients with rheumatoid arthritis: neutrophil-lymphocyte ratio and plateletlymphocyte ratio. Int J Rheum Dis 2015;18:731-5.

27. Fu H, Qin B, Hu Z, et al. Neutrophil- and platelet-to-lymphocyte ratios are correlated with disease activity in rheumatoid arthritis. Clin Lab 2015;61:269-73.

28. Targońska-Stępniak B, Zwolak R, Piotrowski M, Grzechnik K, Majdan M. The Relationship between hematological markers of systemic inflammation (neutrophil-to-lymphocyte, plateletto-lymphocyte, lymphocyte-to-monocyte ratios) and ultrasound disease activity parameters in patients with rheumatoid arthritis. J Clin Med 2020;9:2760.

29. Qin B, Ma N, Tang Q, et al. Neutrophil to lymphocyte ratio (NLR) and platelet to lymphocyte ratio (PLR) were useful markers in assessment of inflammatory response and disease activity in SLE patients. Mod Rheumatol 2016;26:372-6.
30. Wu Y, Chen Y, Yang X, Chen L, Yang Y. Neutrophil-tolymphocyte ratio (NLR) and platelet-to-lymphocyte ratio (PLR) were associated with disease activity in patients with systemic lupus erythematosus. Int Immunopharmacol 2016;36:94-9.

31. Wang L, Wang C, Jia X, Yang M, Yu J. Relationship between neutrophil-to-lymphocyte ratio and systemic lupus erythematosus: a meta-analysis. Clinics 2020;75:e1450. doi: 10.6061/clinics/2020/ e1450.

32. Park Y, Schoene N, Harris W. Mean platelet volume as an indicator of platelet activation: methodological issues. Platelets 2002;13:301-6.

33. Delgado-García G, Galarza-Delgado D, Colunga-Pedraza I, et al. Mean platelet volume is decreased in adults with active lupus disease. Rev Bras Reumatol Engl Ed 2016;56:504-8.

34. Tekeoğlu İ, Gürol G, Harman H, Karakeçe E, Çiftçi İ H. Overlooked hematological markers of disease activity in rheumatoid arthritis. Int J Rheum Dis 2016;19:1078-82.

35. Mercan R, Bitik B, Tufan A, et al. The association between neutrophil/lymphocyte ratio and disease activity in rheumatoid arthritis and ankylosing spondylitis. J Clin Lab Anal 2016;30:597-601.

36. Deng J, Xu S, Gao X, Xu S, Shuai Z, Pan F. Red cell distribution width and mean platelet volume in patients with ankylosing spondylitis: a systematic review and meta-analysis. J Clin Rheumatol 2019; doi:10.1097/rhu.0000000000001174. Online ahead of print.

37. McGonagle D, Aydin SZ, Gül A, Mahr A, Direskeneli H. 'MHCI-opathy'-unified concept for spondyloarthritis and Behçet disease. Nat Rev Rheumatol 2015;11:731-40.

38. Becatti M, Emmi G, Silvestri E, et al. Neutrophil activation promotes fibrinogen oxidation and thrombus formation in Behçet disease. Circulation 2016;133:302-11.

39. Nelson CA, Stephen S, Ashchyan HJ, James WD, Micheletti RG, Rosenbach M. Neutrophilic dermatoses: pathogenesis, sweet syndrome, neutrophilic eccrine hidradenitis, and Behçet disease. J Am Acad Dermatol 2018;79:987-1006.

40. Alan S, Tuna S, Türkoğlu EB. The relation of neutrophil-tolymphocyte ratio, platelet-to-lymphocyte ratio, and mean platelet volume with the presence and severity of Behçet's syndrome. Kaohsiung J Med Sci 2015;31:626-31.

41. Hammad M, Shehata OZ, Abdel-Latif SM, El-Din AMM. Neutrophil/lymphocyte ratio and platelet/lymphocyte ratio in Behçet's disease: which and when to use? Clin Rheumatol 2018;37:2811-7.

42. Vayá A, Rivera L, Todolí J, Hernandez JL, Laiz B, Ricart JM. Haematological, biochemical and inflammatory parameters in inactive Behçet's disease. Its association with red blood cell distribution width. Clin Hemorheol Microcirc 2014;56:319-24.

43. Aksoy Ş N, Savaş E, Sucu M, Kisacik B, Kul S, Zengin O. Association between red blood cell distribution width and disease activity in patients with Behçet's disease. J Int Med Res 2015;43:765-73. 